\title{
DEMOCRACY AND ELITES
}

\author{
DANIEL GAXIE
}

\begin{abstract}
From a sociological point of view the elitist phenomenon must be examined from two angles: the question of renewal of the elites, and that of their unity. When it comes to the question of renewal, internal mobility needs to be distinguished from structural mobility: that is to say, the replacement of one type of elite by another one. For example, could professional politicians give way in the future to amateurs because of the profound mistrust that affects them? Internal renewal is currently limited by the predominantly school-based mode of reproduction that is well demonstrated for the political elite, including the populist political elite, and produces selection effects. About the problem of unity of the elites, there are two distinct questions: are the various elites united, and each one cohesive? The monist hypothesis is faced with difficulties when it is applied to "modern" societies, characterized by a structural differentiation of their sectors of activity. The struggles between elites open up opportunities for the representation of interests of groups outside the elites. Political elites are divided along individual and collective interests and their divisions echo social cleavages. They must be defined and analyzed by their political and ideological tendencies and their links with various groups, but also by their relative positions within political fields. Such hypotheses highlight the distrust in established elites and the populist phenomenon in times of crisis.
\end{abstract}

KEYWORDS: political capital; elites' struggle; establishment and marginality; professionalization; confidence; populism; social divides; school-based legitimacy

Elites are usually regarded as the best members of a group. In this sense, there are elites in all sectors of society. We may speak of blue-collar workers' or sports' elites. In a narrower sense, the elite is the group of people who occupy the highest

1 Emeritus professor of political science at the University of Paris 1 Panthéon-Sorbonne and member of the European Centre for Sociology and Political Science; gaxie@univ-paris1.fr 
rank in society and, more precisely, all individuals wielding important powers: that is to say, economic, political, administrative, media, and intellectual elites.

In its usual sense, the notion of elites may be positive and apologetic or critic and stigmatizing. On the one hand, according to a shared representation, the elites are the best people. They deserve their privileged situations. They have the relevant skills to run the state, the public administration or the economy. In contemporary societies, academic successes are regarded as evidence of elite superiority. Elites are often former students of the most prestigious universities or equivalent establishments, such as institutions of the Ivy League in the USA, Oxbridge in the UK, or Grandes écoles in France. In modern societies, the legitimacy claimed by and for elites is a school-based legitimacy.

On the other hand, critical views stress the closure and privileges of elites, and their domination. These views are more likely to arise in times of crisis when ruling elites are perceived as incapable of coping or unable to cope with problems, and only concerned with their own interests. The existence of a cleavage between masses and elites is a collective representation that can be mobilized in such circumstances. The victory of the vote against the European Constitution in the French referendum in 2005, the pro-Brexit vote in the UK in June 2016, the progression of so-called "populist" parties in numerous European countries, as well as the election of Donald Trump in November 2016, have been analyzed as a movement of revolt against elites.

The cleavage between "masses" and "elites" has perhaps never been more perceptible than in the very contemporary period. Western societies are prosperous and enviable in the eyes of people living in developing countries. However, an increasing number of Westerners believe that their economic and social situation is deteriorating severely for numerous reasons: among other things, unemployment, precariousness, low wages, declining purchasing power, poverty, the financial and economic crisis, public deficits, the dismantling of public services and social policies, austerity policies, migrations, and social inequalities. The "Elites", as they are confusedly perceived, are considered responsible for this situation. The crisis of confidence is especially strong for political and media elites. A growing proportion of citizens considers that politicians are corrupt, think only of their own interests, take advantage of their privileges, are insensitive to the difficulties of ordinary people, speak more than they act, and are only preoccupied by their re-election. Members of educated and politicized people are of the view that, as a result of globalization, political parties and governments can no longer cope with unemployment, offshoring, capital movements, speculation, tax evasion or immigration. Many people believe that, from now on, economics and finance will command politics and even that politics no longer counts (Gaxie 2003 and 2016). 
This general mistrust of politics is reflected in everyday conversations, opinion polls, letters to newspapers, and even more in elections. Electoral abstention is increasing almost everywhere at every election. The tendency is particularly strong among the lower social classes. Abstention is today the first workingclass "political party". Otherwise, the members of the lower classes support right-wing nationalist movements.

The crisis of confidence in politics also affects European institutions and European integration. We know that, in the past, European integration was an elite-based process, facilitated by the weak, superficial, and diffuse support of the other categories. But firmer views have recently been formed among people who were hitherto indifferent to European problems. Their views on Europe are often very negative. In its western part, the European Union is being called into question because of its supposed responsibility for democratic deficit, inflation after the introduction of the euro, invasive and persnickety regulations, dismantling of public services, lack of economic growth, unemployment, offshoring, competition from Eastern workers, social dumping, labor market reforms, and austerity policies. In the countries of Eastern Europe, the EU is criticized for promoting migration and interfering with national domestic problems (Gaxie et. al. 2011). Negative views are particularly widespread among the lower and lower middle classes. It is certainly around European issues that the cleavage between elites and the masses is the most obvious, as observed in the 2005 French referendum on the European Constitution and the 2016 British referendum on "Brexit".

There are also scholarly elitist theories on the critical side of perceptions of the role of elites. They appeared at the turn of the twentieth century in opposition to democratic and socialist currents. Gaetano Mosca, Vilfredo Pareto, and Roberto Michels are regarded as the main theorists representative of this ideological movement (Mosca 1939; Pareto 1963; Michels 2001).

Elitist theories are directed against democracy and Marxism. They contend that, in all societies, including democratic and socialist ones, powers are monopolized and wielded by elites, and that masses are bound to obey them. This thesis calls into question fundamental postulates of democracy. From an elitist perspective, the principle of equality between citizens is illusory. Nor can there be any power of the people. The regimes that claim to organize the power of the people must be analyzed as an ideological mystification, obscuring and legitimizing the power of an elite. Similarly, the affirmation that the main social division is between masses and a ruling elite is an objection to the Marxist theory asserting that society is divided into social classes. From this elitist point of view, there cannot be a proletarian revolution or dictatorship. The so-called proletarian revolution, as well as the power exercised in its name, is controlled, 
as it is always the case, by a revolutionary elite that speak on behalf of the proletariat to take power for their own sake.

These contradictory views reflect social contradictions. In continuation of the ideas of Alexis de Tocqueville (Tocqueville 2004), it is taken for granted that democratic systems need a society of equal citizens. At the same time, democratic societies are also elitist societies. It is therefore still relevant to question the relations between democracy and elites, especially as democratic systems have been confronted with various crises in recent decades.

From a sociological point of view, the elitist phenomenon must be examined from two angles: the question of renewal of the elites, and that of their unity.

\section{RENEWAL OR REPRODUCTION OF THE ELITES?}

A first question, both sociological and normative, is about the degree of internal renewal of the elites. Does each successive generation of a family always belong to the elites of their country, or can we observe a renewal of elite members in each generation? This question is about internal circulation or individual social mobility within the elites.

Internal mobility needs to be distinguished from structural mobility: that is to say, the replacement of one type of elite by another one. For instance, salaried managers have progressively supplanted owners of companies, whether founders or heirs, typical of family capitalism. Top managers may be partly remunerated with shares and therefore associated with ownership, but they are less attached to their companies. They are able to resell their shares at a favorable occasion. Some move from one company to another, following offers of the executive labor market.

Another example of collective structural mobility is the historical replacement of notables by professional politicians. This old process of transformation has recently been reinforced, as can be seen, for example, with the growing number of politicians who have always been active in the political sector and have had no other professional experience. This tendency is perceived in the general public and is one of the many criticisms that fuel anti-political feelings. This is also one of the reasons for the successes of "new" political movements such as the Five Star Movement in Italy and The Republic on the Move in France. Both movements boast of promoting access to power of "amateurs" from civil society. Even if some of these newcomers are in fact real professionals or local elected representatives in the course of professionalization, we may wonder whether these movements could not indicate structural mobility in the political sphere. 
Are these amateurs condemned to become professionals in turn or are they the precursors of a new state of the political system with political institutions led by people who devote themselves to politics for a few years before returning to the civil society after one or two parliamentary terms of office?

The issue of internal renewal is sensitive from a normative point of view. The elitist phenomenon is a challenge for democracies, and representation itself is a challenge. Since the Greek antiquity, elections have been seen as an aristocratic mechanism favoring the recruitment of members of the "best families" and the organization of a division of labor for the benefit of elected officials who monopolize political power and exert their domination over passive citizens (Weber, 1946). If elites exist in society and control the major powers, then the fundamental democratic principle of equality between citizens is undermined. This normative challenge is further aggravated if elites are hereditary. By contrast, opening up access to elites will be considered as "democratization". Greater equality of access to privileged situations would compensate for inequalities between members of society.

The closure of the elites is considered as even more unbearable in times of crisis. They are considered responsible for the misfortunes faced by various categories, while enjoying privileges that protect them from these misfortunes. Marginal political entrepreneurs seeking popular causes demand a profound renewal of the political personnel. Slogans such as "get out!", "clear off", or "leave!" that demonstrators chant in the streets show that they could mobilize on this issue.

The issue of elite renewal is usually dealt with according to a half-full or halfempty glass perspective. We can identify examples of members of the same family who have belonged to the same elite circles over several generations, but it can also be noted that such cases are not very frequent. Thus, for instance, only 5\% of French MPs elected in the 2012 general parliamentary elections, and 6\% of those elected in 2007, were the daughters or sons of elected representatives (my own data).

But this way of considering the question of the internal renewal of elites is perhaps too narrow, and at the same time naïve. In contemporary societies, the intergenerational transmission of social powers occurs mainly through the mediation of the educational system. In other words, the tendency to reproduce family social rank from one generation to the next is mainly based on school mechanisms. Educated families pass on various educational resources, which can be labeled as cultural capital, and which promote the school success of their children at various levels (Bourdieu-Passeron 1990). This transmission is diffuse and only partially intentional and controlled. In a second step, this school achievement will promote social success: that is to say, access to the 
privileged social positions sought at a given moment in historical evolution. In the past, business owners passed on their capital and power directly to their children through inheritance. Today, transmission of economic capital and power is more indirect and takes place, or is at least legitimized, through the family transmission of cultural capital. It is through the same mediation that a few dynasties of political leaders or high civil servants are maintained. More generally it is through such mechanisms of cultural transmission that access to ruling categories is ensured within families. It should be noted that the counterelites who run the populist movements also claim their cultural capital to justify their access to power, and their cultural capital is frequently inherited. Marine Le Pen, for example, often highlights her qualities as a woman, a mother of three, a law graduate and a lawyer when she appears in the official television campaign, and her father is also a law graduate.

The issue of internal renewal of the elites then leads to the question of the equality or inequality of chances of academic successes, also discussed as "democratization" of educational opportunities. This is a question of empirical sociology. Empirical findings show a tendency to reproduce educational achievements from one generation to the next. Children whose parents attended universities are more likely to benefit from university education than those whose parents dropped out at a lower level. Symmetrically, under-representation of students from lower or lower-middle class families increases with the academic level and the prestige of academic institutions. However, this trend is unevenly strong from one country to another. Some national school systems are more likely to reinforce or to weaken the general trend of family transmission of educational opportunities. For example, according to international comparisons, there is a high level of reproduction of educational inequalities in France. Such a tendency is more or less perceived within the population and also fuels opinions hostile to elites, especially mistrust of political elites.

The tendency to family transmission of the chances of formal education and, consequently, of the chances of access to elites is probabilistic. First, this means that the mode of reproduction of contemporary societies is mainly, but not entirely, based on school mechanisms. It follows that, in some cases, access to positions of power, especially political or economic ones, does not depend on academic qualifications. Conversely, even the most sought-after academic titles do not always guarantee access to elites. Second, when it comes to the reproduction of school chances, the correlation between academic levels of parents and children is firmly established, but with varying intensities, and never at the absolute level $(=.1)$. This means that, on average, people whose parents have studied at high levels have higher statistical chances of doing the same as persons whose parents did not. Of course there are also people coming from educated families who do 
not succeed in school, or less than their parents. Conversely, in each generation, there are individuals who pursue brilliant academic careers, which may lead a few of them to enter elite educational institutions, without any parental cultural support. Explanations of such statistical exceptions are numerous and cannot be discussed in this text. There are accidental and structural reasons. Some of the latter are related to the conditions of intra-familial transmission, inter alia the strength of conjugal relationships. Others depend on the extent to which education policies can hinder the tendency towards cultural reproduction. However, exceptions to statistical regularities may also be only apparent. In some cases, school performance actually depends on cultural transmission, but it takes place outside the nuclear family - for example in the extended family, or through other types of important mentors, either neighbors, friends or devoted educators.

But, beyond analyzing the limits and explanations of the internal renewal of the elites, one can also wonder about its sociological importance. We can ask whether the behavior and choices of political and economic elites would be significantly different if their members were totally, or, at least, more recruited, outside the families already members of privileged social categories. In most European countries, there are virtually no former blue-collar workers in parliament, but would public policies be more favorable to working classes if some of their former members were elected? We may contend that attitudes of elites members depend on their structural positions. Whatever their origins, they are placed in position of superiority and power. Even if their origins affect their behavior and choices, this would be in addition and within the limits of other factors, such as considerations associated to state responsibility and contextual constraints of the exercise of power.

Whatever the answers to these questions - and from a normative point of view - opening up access to political elites is considered particularly important for representative democracies. In the absence of true possible equal political roles between "ordinary" citizens and representatives, the diversification of the origin of elected officials is regarded as a token and a guarantee of democratization. This is why the composition of the political elite is an issue and an object of public debate. A candidate in the French presidential election of 2017 regularly boasts of being the only active worker and therefore the only one truly qualified to defend the interests of workers. For the same reason, parliaments often publish socio-demographic information about their members.

Of course, most MPs have lived for and off politics, often for a long time. Such a professionalization is uneven across countries but is tending to strengthen. For example, more than a quarter of French parliamentarians lived off politics before, and many more after, their first election to the National Assembly, and this figure is 
probably underestimated. We observe that a growing proportion of MPs $-12 \%$ of the members of the French National Assembly elected in 2012 (my own data) - have always had full-time paid employment in the political sphere since the end of their university studies. Many of them have been recruited as assistants or members of the entourage of a parliamentarian, a mayor of a large city or a president of a local elected body. Due to their proximity to a political leader, they can be nominated for local elections in an eligible position. They can start a political career, and some of them will replace their former bosses after retirement. Such enhanced political professionalization is considered to be contrary to the democratic principle of equal chances of access to elected offices. This is one of the many reasons for the growth of the great mistrust displayed by many citizens in matters of politics in times of mass unemployment, precariousness, and low wages. These early politicians are also severely criticized for their lack of professional experience outside of politics. The main French public television channel broadcast a report showing that none of the main candidates in the 2017 presidential election had had significant professional experience outside politics. Only two of the eleven candidates to the 2017 French presidential election had a "normal" job outside of politics. These two were members of small Trotskyist parties. In a televised debate, one of them stressed his position as a simple worker in a car factory as an argument to stigmatize his opponents and the many privileges and protections they enjoy as professional politicians, including the candidate of the National Front, who uses her immunity as a member of the European Parliament to refuse to submit to the convocation of a judge.

The hypothesis of a school-based mode of reproduction is well demonstrated for the political elite, including for the populist political elite. For example, more than $90 \%$ of French MPs have received university training. In all European countries, such a percentage has varied since the middle of the nineteenth century, following a V curve. The proportion of MPs with university education was high in the early days of parliamentary democracy. It declined when representatives of the mass-parties (especially worker or Christian Democratic parties) entered the parliaments and it began to rise again after the Second World War (Gaxie-Godmer 2007).

A consequence of such a raising of the level of education of the political elites is a reinforcement of their social selection. For example, $84 \%$ of French MEPs elected in 2012, compared to 74\% in 1959 (my own data), are former members of the higher social categories (entrepreneurs, business executives, members of free or intellectual professions, senior civil servants). However, over the same period, the proportion of these categories within the general population also increased from $6 \%$ to $14 \%$. Political representation always rests on an "inverted pyramid", but the distortion between the weights of the higher categories in 
the population and in the elected institutions diminishes, even if it does not disappear. By contrast, representatives who have personally belonged to the lower and lower middle classes, who still account for more than half of the population, tend to disappear in most Western democracies.

This relative closure of the ruling elites contributes to the distrust in politics that has been increasing for several decades in Western societies, in parallel with the economic difficulties that began with the oil crisis in the 1970s and have never really been overcome. Some speak of a crisis of representative democracy and seek an alternative political system. The utopia of participatory democracy is in the air and on the rise. It is still confined to limited sectors, mainly at the local level. Surveys show that the participants in the participatory institutions belong mainly, if not to the elites, at least to relatively high social categories. Some of them, among the most constant, behave as a counter-elite or are coopted by elected officials.

A second important theoretical issue concerns the unity of elites.

\section{UNITY OR DIVISION OF THE ELITES?}

It is necessary to divide the investigation into two distinct questions: are the various elites united, and each one cohesive?

\section{Monism or pluralism?}

Concerning the first question, the monist arguments hold that the elites are united and share the same values, interests and attitudes. On the other hand, pluralistic theorists insist on the diversity of the elites.

The monist hypothesis is faced with difficulties when it is applied to "modern" societies, characterized by a structural differentiation of their sectors of activity (Parsons 1991; Luhmann 1982). The proposition that modern societies are differentiated implies that they are divided into distinct worlds, relatively separate from one another, with different activities and interests. These worlds are called "spheres", "sectors", "subsystems" or "fields" according to intellectual traditions and theoretical presuppositions.

Hypotheses on differentiation have been developed as arguments against Marxist theories that analyze political parties and actors as representing the interests of classes or class fractions, especially the interests of the ruling 
classes. For example, Joseph Schumpeter argues that when a party is analyzed as a representative of a social group, only one of the many factors that can influence its direction is taken into account. Other important factors are the particular interests of a party, its members, especially its leaders, and even the political class as a whole (Schumpeter 2003). These interests may be individual, collective or corporative. They predominate most often, and the defense of other interests, such as those of a social group, may be carried out, in addition, according to the logic and within the limits of the advancement of specific political interests.

Raymond Aron also criticizes the Marxist theory of a ruling class by insisting that in modern societies there are several ruling categories. Against the Marxist idea that in capitalist societies governments act in the interests of the economic ruling class, he stresses that those who run large private enterprises have no political responsibilities and that political leaders are generally not active businessmen. According to his famous formula "The CEO of the FIAT car company is not the president of the Italian Council" (Aron 1965). Yet, it is true that after the publication of the article by Raymond Aron, a corporate magnate, particularly powerful in the media sector, became the leader of the ruling party and the president of the Italian Council. More recently, a billionaire, owner of several real estate companies, was elected President of the United States. However, these examples remain isolated.

Pierre Bourdieu is one of the sociologists who take up, if not the expression, at least the hypothesis, of the structural differentiation of contemporary societies. He represents a society divided into "fields" - among others, economic, political, administrative, intellectual, religious, scientific, journalistic, etc. -, each with a "relative" autonomy, and whose members struggle for specific issues, interests and investments. In his view, what incites a politician to "run" will leave members of other fields indifferent. Each field is structured by the distribution of a specific capital. For example, in political fields, there is a division between individual and collective actors with a large amount of political capital (for example government parties) and those with a smaller volume (for example fringe parties). Political capital is a kind of symbolic capital. It results from a complex set of acts of recognition by which ordinary citizens, but also members of political worlds, are supposed to support and therefore to accept the power of a politician or a party. The number and percentage of votes that a politician or a party may collect (but also popularity or approval ratings, results of opinion or electoral polls, the number of street protesters or participants in a political rally gathered by an organization, the amount of money that candidates can raise for their campaigns, the number of invitations to television and radio broadcasts, or the number of elected representatives who declare their support for a candidate 
in a first-order election), are objectifications and indicators of political capital. Bourdieu's hypothesis is that the power relations in each field depend on the distribution of the specific capital of the field. Those with the largest amount of specific capital are dominant within their field. The possession of a species of capital is also the foundation of the power exercised over those who remain outside the specialized struggles that develop in each domain. So, specialized agents who participate in the struggles of the political fields dominate ordinary citizens that support them. A division of the labor of domination ensues. Economic, political, intellectual, religious, scientific dominations are distinct. Different agents, whose power rests on different species of capital, exercise them. But their power is circumscribed. There is no class or elite capable of accumulating all the kinds of capital that form the basis of the various powers existing in society (Bourdieu 2016).

Raymond Aron is above all anxious to point out the existence of a plurality of ruling categories, in opposition to the Marxist thesis of the unity of the economic ruling class, which would also be ipso facto politically dominant. He does not comment on the relationships between the ruling categories. For the pluralist tradition with which he may be associated, these relationships remain indeterminate. Political elites can promote various social interests according to power relations between groups and coalitions. Business leaders, as well as unions, can be in a position of strength depending on configurations and contexts.

The hypothesis of structural differentiation is not incompatible with the proposition that different elites can be linked together. Charles Wright Mills, for example, described close ties between corporate elites, especially in the arms sector, senior officials, especially senior military, and political leaders. He said that agents of these three categories constituted the power elite of the United States. This hypothesis has been widely disseminated for some time, with the idea of domination by a military-industrial complex (Wright Mills 1956).

The specialized and segmented elites can also be unified by common values and visions of the world. Numerous sociological analyzes have also shown that various "mechanisms" contribute to the rapprochement of specialized elites in particular economic, administrative and political elites (Pinçon 2007 for a French example). Their members are sometimes born in the same families. They live in the same privileged neighborhoods. They have attended the same elite schools and prestigious universities, and are still sending their children there. They frequent the same inner circles and find themselves in the same holiday locations, the same clubs, and the receptions of common friends.

The members of the different elites also move from one to the other. Some senior civil servants are appointed at the head of big companies or start a political career. Politicians mobilize their address books to create their law or 
consulting firms. Business leaders enter governments. The debates raised by the appointment of a former President of the European Commission to a senior position in a US bank revealed that many European officials have followed the same type of trajectory. However, these movements are asymmetrical. Members of state elites - senior civil servants or military, political leaders - are more likely to turn to business sectors than economic elite are to engage in politics or to access high administrative responsibilities. The resources accumulated by the members of a given elite are unequally effective in encouraging entry into another. These asymmetries are indicators of the unequal social power of the various elites. The tropism that attracts the members of the administrative, political, and even intellectual elites, towards the economic sectors emphasizes that, for the moment at least, the economic elites predominate over the others. The relatively broad consensus within the field of power over the neo-liberal vision of economic elites is a sign of their ideological hegemony.

Against the hypothesis of an ideological unity of segmented elites, Bourdieu proposes the hypothesis of a struggle within the ruling circles. Specifically, he envisages a "field of power" (champ du pouvoir), on which owners of different types of capital struggle against one another to improve the relative value of "their" species in relation to other species. This field of power is structured, inter alia, by recurring confrontations between agents whose positions in society rest on economic and cultural capital. In his analysis, many ideological and political battles are manifestations of the structural opposition between the economic and intellectual bourgeoisies (Bourdieu 2016). The struggles in the field of power also open up opportunities for the representation of interests of groups outside the elites. Intellectuals for instance have often been at the head of workers' political parties and social movements. However, the relative position of elites changes over time. In this sense, we can observe a relative decline of the intellectual elites in recent decades and an ascent of the media elites. The intellectuals, whose social weight has weakened, are less able to challenge the neoliberal consensus as they did in the past.

Questions about elite unity are often raised from an inter-elite viewpoint. They also deserve to be discussed from an intra-elite perspective.

\section{Unity or division of the elites?}

To what extent is each elite divided or united? There are, for example, many well-known fractures that divide economic elites: competition between sectors, for example, between finance and industry; competition within sectors, for example between small and large firms or protectionist agents against free 
traders. The same is true with administrative elites. They are divided between ministries, directorates, bureaus, agencies; between spending and accounting ministries, departments in charge of public order and economy versus social, cultural, and educational units; central state organizations as opposed to devolved and local authorities...

Questions about the unity or division of political elites are particularly relevant because of their effects on the functioning of democracies.

Political elites are divided along individual and collective interests, but, in some circumstances, they tend to unite around common concerns of the political corporation.

Political fields are first of all divided by inter-individual competition. Individual political actors are obviously concerned about their individual situation, especially since many of them are professional politicians who live off politics. For example, many MPs think of their re-election or of their promotion as rapporteur for a text, chairman of a committee or member of the government when they deliver a speech, submit an amendment or vote on a bill.

But politics is more and more a collective enterprise. With a few exceptions, candidates need the support of a party to be elected parliamentarian, mayor of a large city or president of a local representative institution. The situation of individual political actors depends on the success of the organization or coalition to which they belong.

Political elites are thus split between groups that oppose each other according to political, ideological, social, territorial, religious, national and / or ethnic divisions. Due to political competition, collective interests of various kinds have been formed and defended in political arenas. However, a paradox is that the ideological distance between the main established parties has diminished, while the difficulties encountered by Western societies have been aggravated in recent decades. Although traditional political parties claim that they are concerned about important problems, such as unemployment, declining purchasing power, precariousness, immigration, environment, security, terrorism, and public services, a growing number of citizens believe that they do nothing. A window of opportunity has therefore been opened for the parties that present themselves as "anti-system", and are (more or less) perceived by part of the public as different from the established organizations because of their position and behavior as marginal parties and their heterodox positions on various subjects, particularly immigration and European integration.

Political and ideological oppositions and the division of political elites are also linked, among other factors, to differences in the social ties of the political personnel, as can be seen, for example, in the educational and professional backgrounds of members of political parties in Parliament. 
In the French case, personal belonging to the higher social categories before entering the National Assembly was a significant difference between right - and left-wing parties in the past. This difference has been considerably reduced: $80 \%$ of socialist and center-left MPs elected in 2012, and 90\% of their Republicans and center-right colleagues, are former members of the higher social categories (entrepreneurs, business executives, members of free or intellectual professions, senior civil servants). The leaders of the National Front show little difference in this respect to the mainstream political leaders. Differences between right - and left-wing parties are greater when considering the social origin of their family: only $38 \%$ of socialist and left-liberal MPs, but $64 \%$ of conservative and right-liberals, have at least one of their parents belonging to these same higher categories. It is henceforth within these limits that the opposition between right - and left-wing parties echoes the opposition between the high and low positions of the whole social space. However, it must be added that the opposition between right - and left-wing parties also echoes opposition between high and low positions, but in upper social categories. For example, French civil servants are divided into three $-\mathrm{A}, \mathrm{B}, \mathrm{C}-$ hierarchical categories. If we look at the MPs who belonged to the top "A" category before their first election, it can be seen that the right-wing parliamentarians belong more often to the upper echelons and their left-wing counterparts to the categories at the bottom of this category. The same applies to the other high categories. For example there is a social divide between MPs who were salaried managers in the private sector before their election. Left-wing MPs were more often middle managers, especially in cooperatives or in the "third sector" (enterprises set up by associations), than senior executives, and vice versa for right-wing deputies.

In the past, some socialist and, more often, communist politicians, had been blue-collar workers, small employees, or small farmers, often for a short period of time, before starting a political career. There were therefore personal ties between the lower and lower middle classes and the political personnel who claimed to defend their interests. The same was true with some right-wing politicians and lower strata of independent occupations such as shopkeepers or craftsmen. These links have not disappeared but they have been loosened. There is always a correspondence between the political oppositions between the left and right parties on the one hand, and the social divide between the upper and lower classes on the other. However, these relationships are currently based on family and homologous relationships, although they have been established in the past on a more personal, albeit limited to a short period of time, belonging of representatives. There has always been a social distance between the lower classes and those who pretend to be their representatives, but this distance is nowadays certainly greater than it was in the past. 
At the same time, a fairly large proportion of the working classes and the lower middle classes no longer turn out to the polling stations on election days or, when they continue to vote, support the populist parties. Lasting economic hardships have provoked a crisis in the relations between the left parties and the popular categories that supported them in the past. It is interesting to note that one of the many arguments these people put forward to explain why they abstain from voting or why they vote for populist parties, is that traditional politicians belong to privileged circles, do not know their difficulties, and no longer represent them. It would be naïve to think that this explanation is the only true explanation. The problem of the popular classes is not only, and probably not primarily, that of their symbolic representation. Rather, the impotence of left - and right-wing governments to find solutions to the various problems faced by these social groups must be questioned. It is probably related to the inability of or impossibility for national governments to correct the negative consequences of the globalization of economic exchanges for high-wage countries. But this impotence is also accompanied by a lack of political will. Some members of a French socialist think tank have argued that the working classes are no longer attractive from an electoral point of view, and that electoral support must now be sought among other categories, especially educated urban salaried middle classes. The left parties and governments are more willing, or at least more successful, to carry out symbolic societal reforms on gender equality or samesex marriages than traditional social policies.

The opposition between the upper and lower categories of the whole social space or of its sub-spaces is only one of the many dimensions that divide the political elites. Again, the social backgrounds of parliamentary elites bring relevant indications, provided that relative rather than absolute differences are taken into account. In accordance with these methodological principles, it should be noted that in comparison with their left-wing counterparts, members of parliamentary right-wing parties are more often former private sector agents, business leaders, executives, members of independent professions, especially free professions or farmers. Members of the left-wing parties in parliament are more frequently former public sector agents, salaried employees, and members of intellectual professions, especially professors and teachers. Regarding their academic trajectories, rightwing parliamentarians have more frequently attended private primary and high schools, especially religious ones, then institutes of tertiary education, such as engineering or business schools, sometimes elite institutes, where they have received practical or applied education (law, management, medicine, engineering). Members of the left are more frequently former pupils of public elementary and high schools, and former university students, with more intellectual and fundamental specializations (sciences, social sciences, humanities). 
The oppositions between the right - and left-wing parties thus echo several social divisions: independent occupations in relation to the salaried categories; employers versus employees; private in opposition to public sectors; economic against intellectual bourgeoisies; economy and core state institutions such as interior, justice, police, and army ministries, in opposition to education, social and cultural state departments; religious and secular circles, only to mention the documented dimensions.

It follows that political elites are, among others mechanisms, divided according to principles of opposition that exist outside the political worlds, and are thus hetero-determined. This heteronomy of political fields opens up opportunities of representation for various social interests. Due to political competitions, groups that oppose each other in various social cleavages are able to find political representatives. The same is true for categories whose members believe that they have been abandoned by the ruling elites.

These opportunities are generally reinforced by more or less solid and lasting links between social groups and political parties. These links evolve. For example, the socialist parties are now farther from the working class or teachers and closer to the business community than they were in the past.

Such homologies (in the geometric sense) between political oppositions and social divisions are fundamental mechanisms of representative democracy. But these social bases of contentious politics also interfere with specific autonomous political determinations. The very existence of political worlds, relatively separate from other social worlds, with their own games, issues and interests, has an impact on representation mechanisms. The development of political professionalization reinforces the tendency of political representatives to privilege their particular interests. The increase in the number of political actors who have always lived off politics means that their links with social groups, at least the groups to which their predecessors from the same political family had personally belonged in the past, have weakened. Some politicians boasted in the past that they were or had been workers, teachers, farmers or small entrepreneurs as evidence that they were close to their constituents and willing to defend their interests. Nowadays, an increasing number of those who claim such social roots can only say they are the son or the daughter, sometimes the grandchild, of a blue-collar worker, a teacher, a farmer or a small entrepreneur. Enhanced professionalization increases the distance between social groups and representatives.

Also, the parties are stronger defenders of the interests of the social groups that support them when they are entering, or in a marginal position, in a political field, than when they are well established in public institutions. They are more fervent advocates also when they are in the parliamentary opposition or 
campaigning, than when they are in charge of the government. It does not mean that all political actors are cynical. Established political parties, especially when they are in government, are led to consider various contextual constraints and realties (especially economic, legal, budgetary, international, European ones) that their opponents in more marginal positions can more easily ignore. When they are in power, politicians and parties must take into account not only the expectations of those who support them, but also the reactions of groups that oppose their plans or decisions.

Left political parties, for example, are or were on the whole rather close to and favorable to workers and trade unions and more distant from employers and professional organizations. However, when they are in charge of the government, they must take into account the expectations and demands of the latter and they cannot satisfy all the hopes of the former. Symmetrically, right-wing political parties are more sensitive to the concerns of the business community and more resistant to those of public sector workers, employees and their collective organizations. However, when they are in power, it is costly to confront the latter groups and they may consequently be forced to make decisions that do not correspond to their ideological and political orientations. There are similar processes in European politics. Politicians in election campaigns or in the opposition can criticize European institutions and policies, trumpet their willingness to change the rules, alleviate budgetary constraints, and launch growth programs. However, if they win elections and lead the government, they are quickly confronted with the conflicting interests and orientations of other European leaders and they are inevitably obliged to take account of power relations and to accept compromises, sometimes far from their own commitments. This is the reason why the European attitudes of politicians and political parties depend not only on their ideology and on their national experience of European integration (Gaxie \& Hubé 2012), but also on their position in the political power relations. Politicians and parties that are, have been, or are about to be, in charge of the government are generally more inclined to European integration and more aware of the constraints and narrow margins of maneuver in European politics. European orthodoxy is a component of the mainstream politics and conversely Euro-skepticism is a resource of political marginality. In most European countries, critical opinions of the European Union are developed by left-wing or right-wing radical parties, which in most cases have never been responsible for governmental responsibilities or remain peripheral organizations in one way or another. Established political parties, especially when they are in government, are led to consider various contextual constraints and realities (including economic, legal, budgetary, international, European) that their opponents can more easily ignore. Peripheral members 
or internal oppositions of established orthodox political organizations, and also members of marginal sectors of the intellectual or media elites may also express critical views of European integration, especially in countries with a negative collective experience of European integration (Gaxie \& Hubé 2012). The Brexit issue was raised, and the Brexit campaign was led, by the UKIP -a peripheral organization - and by second fiddles of the Conservative party, with the support of the tabloids. Few established parties are Euro-skeptical mostly in countries with a somewhat negative collective experience of European integration - and those which are so tend to soften their views when they are in charge of government. If they persist when they enter government, they are faced with strong reactions from other Member States, European institutions, and mainstream media from most European countries. The ongoing struggles between the Hungarian and Polish governments on the one hand, and the coalition of all the defenders of European integration on the other hand, will be an interesting test of the possibility to maintain heterodox positions within the European Union.

Political parties must be defined and analyzed by their political and ideological tendencies and their links with various groups, but also by their relative positions within political fields. Oppositions between right and left parties, but also between the majority and the opposition, established and marginal, mainstream and anti-system, parliamentary and non-parliamentary organizations, structure political arenas. Populist parties should not only be analyzed and explained by their political and ideological orientations, but also by their specific positions in the political spheres. More specifically, their behavior is a consequence of their ideological orientations and of the opportunities opened up by their position in the political fields. Organizations that occupy fringe positions in the political fields enjoy a variety of benefits, at least in times when the population is facing serious problems. They have never been in a national government or only as secondary partners of a coalition. They cannot therefore be held responsible for the many difficulties encountered by angry citizens. Unlike the ruling parties, they will not be asked why, when they were in government, they did not implement the proposals they put forward during an election campaign. They are able to approve and support all demands and discontents, to politicize all problems, to assert that the established parties are responsible for them and to claim that they would find solutions for each one. They may agree with workers who complain that wages are too low and, at the same time, back small employers who denounce the burdens imposed on businesses. They may even derive political benefits from their internal divisions. For example, leaders of the French National Front opposed a bill to deregulate labor law at the same time that two of their senators proposed amendments that would strengthen 
deregulation. They thus supported both the views of those who opposed and those who supported the deregulation of the labor market. Populist political parties are thus benefiting from the many sufferings that have plagued Western societies for several decades, particularly after the financial and economic crises in 2008, and from the deep resentment towards and mistrust of the ruling elites who are considered responsible for these misfortunes.

They also benefit from the growing anti-European sentiments they have contributed to. Of course, the mistrust of European integration is partly an autonomous movement. People who suffer from the relocation of their factory to another European country or from the requirements of their employer to reduce wages or increase the length of the work week to cope with economic competition, or persons who pay higher taxes to reduce public deficits and meet the requirements of the European Commission, are likely to attribute all their difficulties to, and develop hostility towards, a "Europe" with which they are not very familiar (Gaxie et. al. 2011). But these diffuse discontents have been orchestrated, published, argued and justified, and have thus gained strength, because of the severe criticisms of the EU expressed in the public debate by the radical left and right parties, by protesting fractions within the established parties, as well as by members occupying peripheral positions within the intellectual and media elites.

Their denunciations increase in weight and audience when their electoral successes give "anti-system" parties a greater access to the main television and radio stations. Many citizens believe that, whether right - or left-wing, governments have failed to resolve what they see as a growing number of problems. Some add that they have never tried the populist option. This option seems all the more attractive to some people now that, due to their numerous alarmist prophecies and warnings on the most diverse subjects, the populists have gained credibility on important issues: immigration, Islamism, terrorism, security, social order, national identity, European integration, euro, and free movement of workers in the European Union. In the vocabulary of public policy analysis, they have contributed to the construction of several public problems (Gusfield 1980) and have become the main owner of some of them (Blumler 1971).

In part, politics is a struggle about the vision of social divisions. Due to the rise of workers' parties, society has long been perceived as divided between employers and employees, or between capitalists and workers. The Conservative and Liberal parties have recently succeeded in imposing the vision of an opposition between the public and private sectors, and between workers protected from and those facing globalization. But other predominant representations now oppose "nationals" to "foreigners" or "makers" and "takers", meaning those who work 
and pay for those who do not work and benefit from the collective protection. Such visions help populist parties to assemble a conglomerate of voters with different and sometimes contradictory interests, first and foremost, blue-collar and lower white-collar workers on the one hand, and small employers on the other hand, whose electoral preferences have often been opposed in the past. Such an electoral miracle is possible because and as long as populist parties remain in their relative fringe position within political fields. Presumably, it would be difficult for them to maintain such a miracle if their leaders were integrated into established political elites.

\section{REFERENCES}

Aron, Raymond (1965), "Catégories dirigeantes ou classe dirigeante?", Revue française de science politique, Vol. 15, n, pp. 7-27.

Blumler, Herbert (1971), "Social problems as collective behaviour", Social Problems, 18, pp. 298-306.

Bourdieu Pierre - Jean-Claude Passeron (1990), Reproduction in Education, Society, and Culture, London, Sage, (1970).

Bourdieu, Pierre (2016), Sociologie générale volume 2, Paris, Seuil-Raisons d'agir.

Gaxie, Daniel (2003), "Sur l'humeur politique maussade des démocraties représentatives", in Oscar Mazzoleni, ed., La politica allo specchi. Istituzioni, partecipazione e formazione alla cittadinanza, Bellinzona, Giampiero Casagrande editore, pp. 109-136.

Gaxie, Daniel (2016), "«Plus ça va, moins j'y crois à la politique» Adhésions et pertes d'adhésion cycliques au politique", in collectif SPEL, Les sens du vote. Une enquête sociologique (France 2011-2014), Rennes, Presses Universitaires de Rennes, pp. 179-194.

Gaxie Daniel-Laurent Godmer (2007), "Cultural Capital and Political Selection: Educational Backgrounds of Parliamentarians", in Maurizio Cotta \& Heinrich Best, eds, Democratic Representation in Europe Diversity, Change, and Convergence, Oxford, Oxford University Press, pp. 106-135.

Gaxie Daniel - Nicolas Hubé - Jay Rowell, eds, (2011), Perceptions of Europe. A Comparative Sociology of European Attitudes, Essex, ECPR Press.

Gaxie Daniel - Nicolas Hubé (2012), "Elites' views on European Institutions: National Experiences Sifted through Ideological Orientations", in Heinrich Best, et. alii, eds, The Europe of Elites. A Study into the Europeanness of Europe's Economic and Political Elites, Oxford, Oxford University Press, pp. 122-146. 
Gusfield, Joseph (1980), The Culture of Public Problems. Drinking-Driving and the Symbolic Order, Chicago, University of Chicago Press.

Luhmann, Niklas (1982), The Differentiation of Society, New York: Columbia University Press, (1970).

Michels, Robert (2001), Political Parties A Sociological Study of the Oligarchical Tendencies of Modern Democracies, Kitchener, Ontario, Batoche Books, (1911).

Mills, C. Wright (1956), The power elite, Oxford, Oxford University Press.

Mosca, Gaetano (1939), Elementi di sienza politica, English translation, The Ruling Class, New-York, McGraw-Hill, (1896).

Parsons, Talcott (1991), The Social System, London, Routledge, (1951).

Tocqueville, Alexis de (2004), Democracy in America, New York, The Library of America, (1835).

Pareto, Vilfredo (1963) Treaties on General Sociology: the Mind and Society, New - York, Dover, (1916).

Pinçon Michel-Monique Pinçon-Charlot (2007), Sociologie de la bourgeoisie, Paris, La Découverte.

Schumpeter, Joseph (2003), Capitalism, Socialism, and Democracy, London and New-York, Taylor \& Francis e-Library, (1943).

Weber, Max (1946), Politics as a Vocation, New York, Oxford University Press, (1920). 
